Jurnal Movement and Education

Volume 1 nomor 1

\title{
Evaluasi Perkembangan Prestasi Ekstrakurikuler Futsal SMP Islam Al Azhar 7 Kota Sukabumi 2019/2020
}

\section{Evaluation of the Development of Achievement of Futsal Extracurricular At SMP Islam Al Azhar 7 Sukabumi City In 2019/2020}

\author{
Rafa Athariq \\ Universitas Muhammadiyah, Kota Sukabumi, Jawa Barat, Indonesia \\ rafa.athariq@gmail.com
}

\begin{abstract}
ABSTRAK
Tujuan dari penelitian ini adalah untuk mengetahui perkembangan prestasi ekstrakurikuler futsal SMP Islam Al Azhar 7 Kota Sukabumi serta peran dari berbagai pihak seperti peran pelatih, pemain, dan manajemen/pembina ekstrakurikuler futsal SMP Islam Al Azhar 7 Kota Sukabumi pada tahun 2019/2020.

Teknik pengambilan subjek penelitian atau informan yang di gunakan adalah purposive sampling, dengan kriteria: 1) Informan harus termasuk dalam ekstrakurikuler futsal SMP Islam Al Azhar 7 Kota Sukabumi. 2) Informan adalah orang yang dianggap unggul dan berkuasa, seperti Pelatih, Captain, dan juga Manajemen/Pembina dari ekstrakurikuler futsal SMP Islam Al Azhar 7 Kota Sukabumi. Dengan teknik pengumpulan data yang digunakan yaitu observasi, wawancara, dan dokumentasi, serta teknik analisidata yang digunakan adalah metode Miles dan Huberman yaitu mereduksi data, penyajian data, penarikan kesimpulan. Pada pemeriksaan keabsahan data yang digunakan adalah triangulasi sumber. Ardi Ariansyah menjadi informan utama, karena menjabat sebagai pelatih dan juga sebagai manajemen/pembina dari ekstrakurikuler futsal SMP Islam Al Azhar 7 Kota Sukabumi.

Hasil dari penelitian sebagai berikut: 1) Belum maksimalnya program yang diberikan oleh pelatih. 2) Belum maksimalnya prestasi ekstrakurikuler futsal SMP Islam Al Azhar 7 Kota Sukabumi pada tahun 2019/2020. 3) Belum lengkapnya sarana dan prasaran untuk menunjang kebutuhan pada saat latihan. 4) Kurangnya dukungan penuh dari berbagai pihak yang menyebabkan terhambatnya proses latihan. 5) Program yang telah dibuat belum maksimal dan program akan dirubah agar menjadi lebih baik kedepannya.
\end{abstract}

Kata Kunci: Ekstrakurikuler, Evaluasi, dan Perkembangan Prestasi

\section{ABSTRACT}

The objective of this study was to determine the development of achievement of futsal extracurricular at SMP Islam Al Azhar 7 Sukabumi City and the role of various parties, such as the role of coaches, players, and management/supervisor of futsal extracurricular at SMP Islam Al Azhar 7 Sukabumi City in 2019/2020.

The sampling technique of the research subjects or informants used was purposive sampling, with the following criteria: 1) The informant must be a part of the futsal extracurricular at SMP Islam Al Azhar 7 Sukabumi City. 2) The informant is a person who is considered superior and powerful, such as Coach, Captain, and also Management/Supervisor of futsal extracurricular at SMP Islam Al Azhar 7 Sukabumi City. The data collection techniques used were observation, interviews, and documentation, and the data analysis technique used was the Miles and Huberman method, including data reduction, data display, conclusion drawing. The data validity test used was source triangulation. Ardi Ariansyah was the main informant since he served as a coach and also as a management/supervisor of futsal extracurricular at SMP Islam Al Azhar 7 Sukabumi City. 
The results of the study were as follows: 1) The program provided by the coach has not been maximally carried out. 2) The futsal extracurricular achievements of SMP Islam Al Azhar 7 Sukabumi City in 2019/2020 were not maximal. 3) The facilities and infrastructure to support the needs during training were not complete. 4) Lack of full support from various parties has inhibited the training process. 5) The program that has been made has not been maximally carried out and it will be changed to be better in the future.

\section{Keywords: Evaluation, Development of Achievement, and Extracurricular}

\section{PENDAHULUAN}

Olahraga sangat penting bagi kehidupan dan saat ini olahraga mengalami kemajuan yang begitu pesat. Saat ini hampir semua orang senang berolahraga. Olahraga sudah menjadi gaya hidup yang tidak dapat dipisahkan dari masyarakat saat ini. Tujuan seseorang berolahraga bermacam-macam, ada yang bertujuan untuk kesehatan, kebugaran, rekreasi, dan mengisi waktu luang. Tujuan utama olahraga yaitu untuk meraih prestasi.

Sekolah merupakan institusi formal. Secara fundamental sekolah berfungsi memberikan pengetahuan, keterampilan serta kemampuan sebagai bekal dimasa depan sehingga dapat menyalurkan bakat dan potensi diri. Sekolah juga merupakan lembaga pendidikan yang sistematis, teratur, bertingkat, memiliki syarat, dan tujuan yang jelas. Manajemen peserta didik merupakan usaha yang menunjang proses kegiatan siswa. Dengan manajemen yang baik, sekolah dapat mengembangkan potensi, minat, bakat, dan hobi yang dimiliki peserta didik untuk mengikuti salah satu program kegiatan yang disebut ekstrakurikuler.

Ekstrakurikuler adalah kegiatan yang dilakukan peserta didik diluar jam pelajaran. Kegiatan-kegiatan ini ada pada setiap jengjang pendidikan dari sekolah dasar hingga universitas. Tujuan dari kegiatan ekstrakurikuler yaitu untuk mengembangkan bakat dan minat peserta didik diluar bidang akademik. Diadakannya kegiatan ekstrakurikuler untuk peserta didik diharapkan mampu memperkaya wawasan, memperluas diri, meningkatkan pengetahuan, memperdalam minat, dan hobi dengan cara yang terarah, dan menjadi sebagai wadah pemersatu hubungan antar pelajar.

Dari hasil observasi yang dilakukan peneliti di Sekolah Menengah Pertama (SMP) Islam Al Azhar 7 Kota Sukabumi meliputi berbagai bidang seperti karya ilmiah, kesenian, keagamaan, dan olahraga. Salah satu kegiatan olahraga adalah futsal. Kegiatan ekstrakurikuler futsal sangat diminati oleh siswa dari kelas VII sampai kelas IX.

Ada banyak olahraga yang dipertandingkan salah satunya yaitu olahraga futsal. Olahraga futsal sangat populer diseluruh kalangan mulai dari anak-anak hingga dewasa memainkan olahraga futsalm untuk mengisi waktu luang. Permainan futsal sudah sangat 
berkembang terbukti dengan banyaknya event-event turnamen yang dilaksanakan. Salah satunya di Kota Sukabumi yang selalu dilaksanakannya turnamen secara continue. Mulai dari ajang turnamen antar SD, SMP, Perguruan Tinggi dan juga untuk umum.

Berdasarkan uraian di atas peneliti tertarik melakukan penelitian lebih lanjut mengenai perkembangan prestasi SMP Islam Al Azhar 7 Kota Sukabumi. Dari observasi yang dilakukan peneliti menemukan rumusan masalah yang akan diteliti sebagai berikut:

1. Bagaimana perkembangan prestasi ekstrakurikuler futsal SMP Islam Al Azhar 7 Kota sukabumi?

2. Bagaimana peran siswa sebagai pemain mengembangkan ekstrakurikuler futsal SMP Islam Al Azhar 7 Kota Sukabumi?

3. Bagaimana peran pembina/guru ekstrakurikuler futsal SMP Islam Al Azhar 7 Kota Sukabumi?

Dari rumusan masalah di atas, maka tujuan yang ingin dicapai dari penelitian ini adalah sebagai berikut:

1. Mengetahui dan menganalisa perkembangan prestasi ekstrakurikuler futsal SMP Islam Al Azhar 7 Kota sukabumi?

2. Mengetahui dan menganalisa peran siswa sebagai pemain mengembangkan ekstrakurikuler futsal SMP Islam Al Azhar 7 Kota Sukabumi?

3. Mengetahui dan menganalisa peran pembina/guru ekstrakurikuler futsal SMP Islam Al Azhar 7 Kota Sukabumi?

Dalam penelitian ini, peneliti bermaksud untuk mengevaluasi perkembangan prestasi ekstrakurikuler futsal SMP Islam Al Azhar 7 Kota Sukabumi dengan menggunakan metode Contex, Input, Process, Product (CIPP).

Menurut Edwin dalam Mahirah (2017:258) "mengatakan bahwa evaluasi mengandung pengertian suatu tindakan atau proses dalam menentukan nilai sesuatu." Menurut M. Ngalim Purwanto dalam Mahirah (2017:262) "bahwa kewajiban bagi setiap guru untuk melaksanakan kegiatan evaluasi itu".

Menurut Darodjat dan Wahyudhiana M (2015: 5), "konsep evaluasi model CIPP (context, input, process, and product) pertama kali di kenalkan oleh Stufflebeam pada 1965 sebagai hasil usahanya mengevaluasi ESEA (the Elementary and Secondary Education Act)". Menurut Madaus, Scriven, Sufflebeam dalam Darodjat dan Wahyudhiana M (2015: 5), "tujuan penting evaluasi model ini bukanlah membuktikan tetapi meningkatkan". Ada empat dimensi dalam evaluasi Stufflebeam ini yaitu meliputi: Context, input, process, dan product. Dari sinilah terbentuk model evaluasi CIPP. Keempat kata dalam singkatan CIPP merupakan sasaran evalusi sebagai komponen dan juga proses program kegiatan.

1. Evaluasi Konteks (Contex Evaluation) 
Menurut Stufflebeam dan Shinkfield dalam Darodjat dan Wahyudhiana M (2015: 6), evaluasi konteks berusaha mengevaluasi status objek secara "keseluruhan, mengidentifikasi kekurangan, kekuatan, mendiagnosa problem, dan memberikan solusinya, menguji apakah tujuan dan prioritas disesuaikan dengan kebutuhan yang akan dilaksanakan".

\section{Evaluasi Masukan (Input Evaluation)}

Menurut Stufflebeam \& Shinkfield dalam Darodjat dan Wahyudhiana M (2015: 6-7) "orientasi utama evaluasi input adalah menentukan cara bagaimana tujuan program dicapai. Evaluasi masukan dapat membantu mengatur keputusan, menentukan sumbersumber yang ada, alternatif apa yang diambil, apa rencana dan strategi untuk mencapai tujuan, bagaimana prosedur kerja untuk mencapainya". Ada empat komponen evaluasi masukan yaitu: (1) sarana dan peralatan pendukung, (2) sumber daya manusia, (3) berbagai prosedur dan aturan yang diperlukan, dan (4) dana/anggaran.

\section{Evaluasi Proses (Process Evaluation)}

Menurut Worthen \& Sanders dalam Darodjat dan Wahyudhiana M (2015: 7) menjelaskan bahwa, "evaluasi proses menekankan pada tiga tujuan (1) do detect or predict in procedural design or its implementation during implementation stage, (2) to provide information for programmed decisions and, (3) to maintain a record of the procedure as it occurs". Evaluasi ini melihat bagaimana proses kegiatan berlangsung. Dengan memperhatikan sesuai atau tidaknya pelaksanaan dengan aturan yang sudah dibuat.

\section{Evaluasi Hasil (Product Evaluation)}

Menurut Sax dalam Darodjat dan Wahyudhiana M (2015: 8), “fungsi evaluasi hasil adalah membantu untuk membuat keputusan yang berkenaan dengan kelanjutan, akhir dan modifikasi program, apa hasil yang telah dicapai, serta apa yang dilakukan setelah program itu berjalan".

Menurut beberapa pendapat diatas dapat dikatakan evaluasi produk mempunyai tujuan penilaian dengan mengukur keberhasilan dan pencapaian tujuan yang sudah ditetapkan. Program dapat teruskan, dimodifikasi, atau juga harus dihentikan sesuai dengan data yang dihasilkan.

Dewan dari Europe's European Sports Charter yang diadopsi pada tahun 1992 dalam Kristianto Wibowo, M. Furqon Hidayatullah, Kiyatno (2017:10) "mendefinisikan olahraga sebagai segala bentuk aktivitas fisik yang melalui partisipasi yang santai atau terorganisir, bertujuan mengekspresikan atau meningkatkan aktivitas kebugaran fisik dan kesehatan 
mental, membentuk hubungan sosial atau memperoleh hasil di kompetisi di semua tingkatan (Council of Europe, 1992)".

Menurut Wahjosumidjo dalam imam (2017:7) "bahwa kegiatan ekstrakurikuler adalah kegiatan yang diselenggarakan diluar jam pelajaran yang tercantum dalam susunan program sesuai dengan keadaan dan kebutuhan sekolah". Menurut Asmani dalam Ria (2016:137) adalah kegiatan pendidikan diluar jam mata pelajaran dan pelayan konseling untuk membantu pengembangan peserta didik sesuai dengan kebutuhan, potensi, bakat, dan minat mereka melalui kegiatan yang secara khusus diselenggarakan oleh pendidik dan atau tenaga kependidikan yang berkemampuan dan berwenang di sekolah. menurut Karim dalam Ria (2016: 137) melalui ekstrakurikuler siswa diarahkan memiliki karakter yang abadi dan universal seperti kejujuran, kedisiplinan, menghargai pluralisme, mempunyai empati dan simpati. Semua aspek ini akan sangat menunjang kesuksesan peserta didik kelak di masa mendatang.

Dalam penelitian ini, peneliti menemukan referensi dari penelitian terdahulu yang menggunakan metode CIPP seperti:

1. Penelitian Kamal Firdaus (2011) yang berjudul "Evaluasi Program Pembinaan Olahraga Tenis Lapangan di Kota Padang." Hasil dari penelitian ini menyatakan Konteks, kualitas masukan, proses dan produk pembinaan olahraga tenis lapangan yang ada di Kota Padang, sudah pada kondisi yang baik.

2. Penelitian Kristianto Wibowo, M. Furqon Hidayatullah, dan Kiyatno (2017) yang berjudul "Evaluasi Pembinaan Prestasi Olahraga Bola Basket di Kabupaten Magetan”. Hasil dari penelitian ini menurut peneliti telatnya pengenalan olahraga basket di Kabupaten Magetan dalam pembinaan usia dini membuat terhambatnya mencapai prestasi tertinggi. Rata-rata pengenalan olahraga bola basket terjadi diusia SMA.

3. Penelitian Agung Sumarno (2016) yang berjudul "Evaluasi Program Pembinaan Intensif Komite Olahraga Nasional Indonesia Sumatra Utara tahun 2009-2012”. Hasil dari penelitian ini menurut peneliti bahwa pemerintah mendukung dalam bentuk kebijakan, anggaran, sumberdaya manusia.

4. Penelitian Shamsa Aziz (2018) yang berjudul "Implementation of CIPP Model for Quality Evaluation at School Level: A Case Study”. Hasil penelitian ini menurut peneliti bahwa semua proses di fokuskan pada siswa, terutama yang berasal dari masyarakat menengah. Sistem sekolah ini menyediakan pendidikan yang berkualitas dan fasilitas yang layak bagi siswa. Dalam penelitian ini peneliti mengutip model evaluasi CIPP untuk mengevaluasi perkembangan prestasi. 
5. Penelitian Guili Zhang, Nancy Zeller et al (2011) "Using the Context, Input, Process, and Product Evaluation Model (CIPP) as a Comprehensive Framework to Guide the Planning, Implementation, and Assessment of Service-learning Program”. Hasil penelitian ini menunjukan bahwa para pembaca beresiko mendapat manfaat dari proyek melalui peningkatan kemampuan membaca, harga diri, dan persepsi diri sebagai diri mereka sendiri. Model evaluasi CIPP berfungsi sebagai kerangka pedoman dan secara sistematis memandu konsepsi, desain, implementasi, dan penilaian proyek pembelajaran layanan ini dalam pendidikan guru.

6. Penelitian Karatas Hakan (2011) “CIPP Evaluation Model Scale: Development, Reliabity, and Validity”. Menurut peneliti hasil penelitian ini mungkin menarik bagi pendidik dan untuk proses pendidikan. Artinya, skala tersebut dapat digunakan sebagai instrumen yang efisien untuk mengevaluasi kurikulum di setiap saat. Ini dapat membuka perspektif baru di bidang evaluasi dan penilaian kurikulum.

Dengan demikian Evaluasi Perkembangan Prestasi Ekstrakurikuler Futsal SMP Islam Al Azhar 7 Kota Sukabumi 2019/2020 adalah suatu unit atau kesatuan kegiatan yang bertujuan mengumpulkan informasi tentang realisasi atau implementasi dari suatu kebijakan, CIPP (Contex, Input, Proses dan Produk) berlangsung dalam proses yang berkesinambungan, dan terjadi dalam suatu organisasi yang melibatkan sekelompok orang guna pengambilan keputusan.

\section{METODE PENELITIAN}

Tempat penelitian ini dilakukan di SMP Islam Al Azhar 7 Kota Sukabumi. Subjek penelitian dalam penelitian ini adalah pelatih, pemain, dan pembina/manajemen. Metode yang digunakan dalam penelitian evaluasi perkembangan prestasi ini adalah CIPP Model (Stuflebeam's) ditinjau dari tahapan-tahapan Context, Input, Proses dan Product. Artinya untuk memperoleh informasi yang akurat dan objektif serta membandingkan apa yang telah dicapai.

Adapun penelitian ini menggunakan metode kualitatif. Menurut Sugiyono (2018: 9) "Metode penelitian kualitatif adalah metode penelitian yang berlandaskan pada filsafat postpoitivisme, digunakan untuk meneliti pada kondisi objek yang alamiah, dimana peneliti adalah sebagai instrumen kunci, teknik pengumpulan data di lakukan secara triangulasi (gabungan), analisis data bersifat induktif/kualitatif, dan hasil penelitian kualitatif lebih menekankan makna dari pada generalisasi”.

Dalam hal ini peneliti itu sendiri yang menjadi alat penelitian atau instrumen penelitian. Dikarenakan dalam penelitian kualitatif ini segala hal yang akan dicari dari objek 
penelitian belum jelas dan belum pasti masalahnya, sumber datanya, hasil yang diharapkan pun belum jelas. Menurut Creswell dalam Conny (2010: 7) "mendefinisikannya sebagai sesuatu pendekatan atau penelusuran untuk mengeksplorasi dan memahami suatu gejala sentral. Untuk mengetahui gejala sentral tersebut peneliti mewawancarai informan dengan mengajukan pertanyaan yang umum dan agak luas". Dalam penelitian ini digunakan alat bantu untuk menjaring data dengan cara mewawancara informan melalui pedoman wawancara, serta juga perlengkapan lain seperti alat perekam suara dan juga alat untuk dokumentasi.

Dalam penelitian ini teknik sampling yang digunakan adalah purposive sampling. Menurut Sugiyono (2018: 218) "Purposive Sampling adalah teknik pengumpulan data dengan pertimbangan tertentu, misalnya orang tersebut yang dianggap paling tahu tentang apa yang kita harapkan, atau mungkin sebagai penguasa sehingga memudahkan peneliti menjelajahi objek/situasi sosial yang diteliti”.

Dalam memperoleh data peneliti berhadapan langsung dengan informan untuk mendapatkan data yang akurat, agar peneliti dalam melakukan pengolahan data tidak mengalami kesulitan. Peneliti membagi menjadi tiga bagian sumber data yaitu. Pelatih ekstrakurikuler Futsal SMP Islam Al Azhar 7 Kota Sukabumi. Pemain/Captain ekstrakurikuler Futsal SMP Islam Al Azhar 7 Kota Sukabumi sebagai perwakilan seluruh pemain. Pengurus/pembina ekstrakurikuler Futsal SMP Islam Al Azhar 7 Kota Sukabumi.

Teknik pengumpulan data dalam penelitian ini, peneliti melakukan pengamatan langsung pada lokasi penelitian yang bertempat di SMP Islam Al Azhar 7 Kota Sukabumi. Untuk mencari data yang objektif, maka peneliti menggunakan observasi, wawancara, dan dokumentasi sebagi tanda untuk memperoleh data yang dibutuhkan. Menurut Sugiyono (2018: 243) "Data yang diperoleh dari beberapa sumber dari berbagai sumber menggunakan teknik pengumpulan data yang bermacam-macam (trianggulasi), dan dilakukan secara terus menerus sampai datanya jenuh.” Sedangkan menurut Miles dan Huberman dalam Sugiyono (2018: 243) The most serious and central difficulty in the use of analysis are not well formulate." Yang paling serius dan sulit dalam analisis data kualitatif adalah karena, metode analisi belum dirumuskan dengan baik.

Setelah pengumpulan data dilakukan, maka selanjutnya data akan diuji keabsahan datanya dengan uji validitas. Seperti yang dikemukakan oleh Susan Stainback dalam Sugiyono (2018: 268) menyatakan bahwa penelitian kualitatif lebih kepada aspek validitas. Oleh sebab itu peneliti harus menentukan cara yang tepat dalam mengembangkan uji validitas 
data yang didapatnya. Dengan demikian penilitian ini akan menggunakan teknik pemeriksaan data dalam mengembangkan uji validitas sebagai berikut ini:

Triangulasi

Triangulasi merupakan suatu teknik keabsahan data dalam mengembangkan uji validitas sebagai pembanding terhadap data itu. Dalam hal ini penelitian ini menggunakan triangulasi sumber. Menurut Sugiyono (2018: 274) "triangulasi sumber untuk menguji kredibilitas data dilakukan dengan cara mengecek data yang diperoleh melalui beberapa sumber”.

Bahan referensi

Arti penggunaan bahan referensi disini adalah sebuah bahan pendukung dalam membuktikan data yang sudah peneliti temukan. Mislanya, dalam hasil data dari wawancara perlu adanya dukungan rekaman wawancara, foto, dan juga dokumen untuk mendukung suatu kredibilitas data.

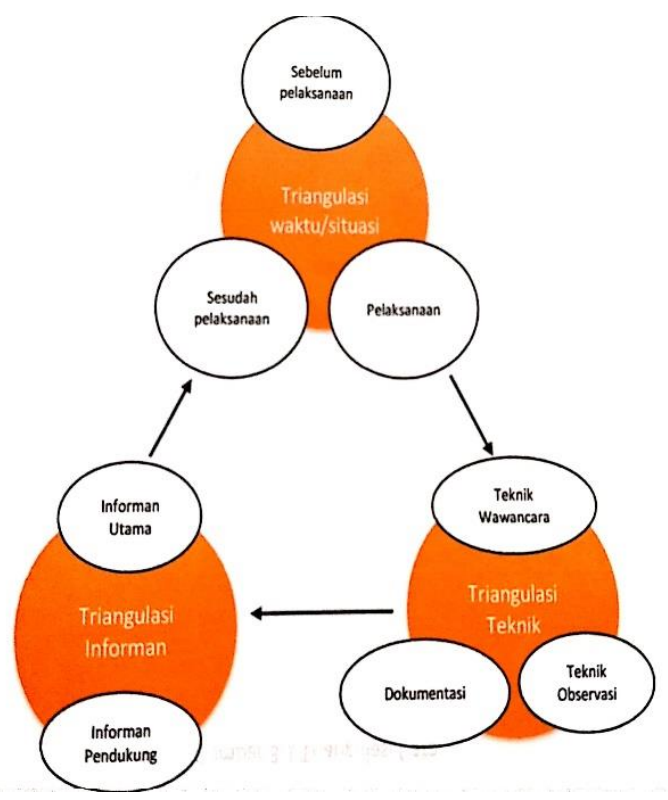

Gambar 2.1 Triangulasi Data

\section{HASIL DAN PEMBAHASAN}

Berdasarkan hasil wawancara dengan pelatih, pemain, dan manajemen/pembina yang berkaitan dengan metode CIPP dalam proses pengembangan prestasi ekstrakurikuler futsal SMP Islam Al Azhar 7 Kota Sukabumi dapat disimpulkan dengan cara trianggulasi data yang sesuai pertanyaan mengenai Context, Input, Process, Product. Adapun pembahasannya sebagai berikut.

Pemain menginginkan prasarana yang dibutuhkan saat latihan dicukupi agar pemain bisa berlatih dengan serius dan semangat. Namun pelatih menginginkan agar siswa yang 
mengikuti ekstrakurikuler futsal agar lebih focus dan disiplin saat mengikuti latihan. Pelatih juga menargetkan agar tim ekstrakurikuler futsal dapat memenangkan kejuaraan yang ada. Dan manajemen/pembina menitip beratkan agar siswa yang mengikuti ekstrakurikuler futsal dapat disiplin dan focus terhadap apa yang di rencanakan oleh pelatih dan manajemen/pembina.

\section{Context}

Prioritas pemain, pelatih, dan manajemen/pembina tentunya ingin memajukan prestasi ekstrakurikuler futsal lewat cabang olahraga futsal, agar dapat mewujudkan tujuan tersebut pemain, pelatih, dan manajemen/pembina harus bekerja sama untuk dapat menjalankan program. Namun terdapat beberapa hambatan yang dijumpai dalam mencapai target yang sudah ditentukan tersebut. Salah satunya kurangnya prasarana saat pelatihan berlangsung oleh sebab itu pelatih harus menyesuaikan waktu dan membagi tim ekstrakurikuler futsal menjadi beberapa kelompok saat latihan berlangsung. Dengan adanya prasarana yang mencukupi pemain akan berlatih secara teratur dan pelatih dapat mengefisienkan waktu latihan agar dapat memberikan teori yang lain.

Input

Dalam mencapai mencapai target yang sudah ditentukan, tentunya harus disiapkan dari awal dengan baik. Salah satunya dengan kelengkapan sarana dan prasarana yang lengkap agar latihan lebih tertuju dan fokus. Diberikan aturan-aturan yang mendukung selama proses perencaan berlangsung agar dapat memberikan dukungan terhadap siswa. Selain itu diperlukan dukungan penuh dari pihak sekolah dan orang tua untuk meningkatkan motivasi siswa agar meraih prestasi di bidang olahraga futsal. Dalam membentuk sebuah tim yang bagus diperlukan kriteria yang harus dimiliki pelatih, pemain, dan manajemen/pembina agar kualitas tim meningkat

\section{Process}

Proses pelaksanaan latihan tersendat karena kurang komplitnya pemain dan pransarana saat latihan berlangsung. Bukan hanya itu saja kurangnya dukungan finansial terhadap ekstrakurikuler futsal menjadi salah satu hambatan yang terjadi oleh karena itu para pemain diharuskan membayar iuran untuk mengurangi hambatan tersebut. Kurangnya keterlibatan dari pihak lain dapat mempengaruhi proses bejalannya latihan. Tetapi jika adanya dukungan dari pihak lain akan sangat membantu proses berjalannya pelaksanaan program yang sudah direncanakan dan proses latihan akan berjalan lebih baik dan teratur.

\section{Product}

Meskipun belum bisa mencapai target yang sudah direncanakan. Tetapi pemain dapat menjalankan apa yang diperintahkan dengan baik. Dan berhasil membuktikan peningkatan 
yang cukup signifikan saat bertanding meskipun belum bisa membawa tim ekstrakurikuler futsal SMP Islam Al Azhar 7 Kota Sukabumi menjadi juara dan memberikan prestasi untuk sekolah. dengan belumnya tercapai target, maka dari itu program yang sudah dibuat dirasa belum maksimal dan akan dirubah agar lebih baik lagi saat menghadapi kejuaraan yang akan datang.

\section{KESIMPULAN}

Berdasarkan hasil penelitian dan pembahasan di atas dapat peneliti evaluasi perkembangan prestasi ekstrakurikuler futsal SMP Islam Al Azhar 7 Kota Sukabumi 2019. Adanya perkembangan prestasi pada ekstrakurikuler futsal SMP Islam Al Azhar 7 Kota Sukabumi tahun 2019. Kurang lengkapnya prasarana latihan menyebabkan proses pelaksanaan pelatihan terganggu. Sebaiknya pihak sekolah dapat memberikan prasarana yang lengkap untuk proses pelaksanaan latihan agar tidak membebani tugas pelatih dan manajemen/pembina. Hanya ada beberapa pemain yang dapat menerapkan hasil pelatihan saat pertandingan. Ini akibat dari perbedaan kemampuan pemain dari segi individu maupun kerjasama tim dan juga kurang seriusnya pemain saat mengikuti latihan. Sebaiknya pelatih dan manajemen/pembina membuatkan peraturan yang dapat meningkatkan keterampilan pemain agar dapat mengikuti pelatihan dengan lebih serius. Kurangnya keterlibatan dari pihak sekolah dan orang tua siswa membuat pelaksanaan pelatihan tidak berjalan dengan baik seperti yang sudah direncanakan dari awal. Sebaiknya pihak sekolah mendukung dan memberikan motivasi kepada siswa yang mengikuti ekstrakurikuler futsal. Kurangnya perhatian lebih dari berbagai pihak menyebabkan proses pelatihan terhambat terlebih kurangnya peralatan saat pelatihan dan kurangnya pemasukan dana saat mengikuti kejuaraan. Sebaiknya pihak terkait dapat membantu berjalannya ekstrakurikuler futsal dari segi psikis dan juga dana, agar dapat mengangkat mental para pemain saat pertandingan.

\section{DAFTAR PUSTAKA}

Azis, Shamsa. (2018). Implementation of CIPP Model for Quality Evaluation at School Level: A Case Study. Journal of Education and Eduacional Development. 5, (1), 189206.

Darodjat dan M, Wahyudhiana. (2015). Model Evaluasi Program Pendidikan. Islamadina. XIV, (1), 2-28.

Firdaus, Kamal. (2011). Evaluasi Program Pembinaan Olahraga Tenis Lapang di Kota Padang. Jurnal Media Ilmu Keolahragaan Indonesia.

Hakan, Karatas, Seval, Fer. (2011). CIPP Evaluation Model Scale: Development, Reliability, and Validity. Procedia Social and Behaviolal Sciences. 15, 592-599. 
Lestari, R, Y. (2016). Peran kegiatan Ekstrakurikuler dalam Mengembangkan Watak Kewarganegaraan Peserta Didik. Untirta Civic Education Journal. 1, (2), 127-132.

Mahirah, B. (2017). Evaluasi Belajar Peserta Didik (Siswa). Jurnal Idaarah. 1, (2), 257-267.

Semiawan, Conny, R. (2010) Metode Penelitian Kualitatif jenis, Karakteristik, dan Keunggulan. Jakarta: PT. Grasindo.

Sugiono. (2018). Metode Penelitian Kuantitatif, Kualitatif, dan R\&D (27th ed.). Bandung: Alfabeta, CV.

Sumarno Agung. (2016). Evaluasi Program Pembinaan Insentif Komite Olahraga Nasional Indonesia Sumatra Utara 2009-2012. Jurnal Ilmu Keolahragaan. 15, (1), 99-133.

Wibowo, Kristanto., Hidayatullah, M.F. dan Kiyatno. (2017). Evaluasi Pembinaan Prestasi Olahraga Bola Basket di Kabupaten Magetan. Jurnal Media Ilmu Keolahragaan Indonesia. 7, (1), 10-15.

Zhang, Guili, Zeller, Nancy. Et al (2011). Using the Contex, Input, Process, and Product Evaluation Model (CIPP) as a Comprehensive Framework to Guide the Planning, Implementation, and Assessment of Service Learning Program. Journal of Higger Education Outreach and Enggement. 15, (4), 58-83. 